\title{
Understanding Performance Indicators of Organizational Achievement in Turkish Airline Companies
}

\author{
Dilek Erdogan (Corresponding author) \\ Department of Aviation Management, Faculty of Aeronautics and Astronautics \\ Anadolu University, Eskisehir, Turkey \\ Tel: 90-222-321-3550 / 6984 E-mail: dilekc@anadolu.edu.tr
}

Ergun Kaya

Department of Management, Faculty of Business Administration

Anadolu University, Eskisehir, Turkey

Tel: 90-222-335-05-80/2544Ｅ-mail: ergunk@anadolu.edu.tr

Received: Sep. 16, $2014 \quad$ Accepted: Oct. 13, $2014 \quad$ Published: October 13, 2014

doi:10.5296/jmr.v6i4.6355 URL: http://dx.doi.org/10.5296/jmr.v6i4.6355

\begin{abstract}
The aim of this study is to analyze performance indicators used by airline companies within the framework of a performance and strategic management tool, namely, 'balanced scorecard (BSC)', and to assess its applicability in the airline business. Designed as a multiple case study by collecting data from primary and secondary sources, the participants of this study are scheduled airline businesses operating in Turkey. The airline companies have been found to use similar performance indicators within the financial, customer-based, internal business process, and learning/growth perspectives of BSC. Airline companies are recommended to use BSC because it allows them to transform their strategies into measurable performance indicators and to assess their performance multi-dimensionally.
\end{abstract}

Keywords: Strategic Management, Performance Management, Balanced Scorecard, Airline Industry, Performance Indicators 


\section{Introduction}

Airline businesses operate in an industry that employs a large number of personnel and which requires huge amounts of infrastructure and aircraft investment. Therefore, the fixed costs of airline companies are quite high (Morrell, 2007). In addition to these high fixed costs, they have to operate in an intensely competitive environment where many airline businesses offer similar services with minimal profit margins. Due to such a highly competitive environment, most operating airlines feel pressured to quickly respond to demands in order to survive (Doganis, 2002). Thus, performance management has become a vital issue for airline businesses, and the need for performance tools to assess their current and future performance multi-dimensionally has increased (Khim et al., 2010).

Having effective performance management in place is highly critical to ensure successful implementation of a business strategy. Through such a performance management system, whether shareholder demands have been met and whether pre-determined objectives have been accomplished can be evaluated (Neely et al., 2005). To deem themselves successful, businesses today are not only satisfied by good performance on cost-efficiency, but also strive to show good performance on other non-financial criteria, such as quality, flexibility, value-creation and customer satisfaction (CIMA, 2002). Consequently, performance measurements based only on financial criteria are insufficient for the assessment of business performance, and are inadequate in measuring factors that are important for a business (Neely, 1999). Therefore, businesses need non-financial performance indicators, as well as financial indicators in accordance with their strategy, to successfully apply performance management, which requires the use of multi-dimensional performance management systems in businesses (Kaplan and Norton, 1996). As one such multi-dimensional performance management tools, $\mathrm{BSC}$ is a performance and strategic management tool that turns the strategy and vision of a business into a balanced set of criteria. Via the use of BSC, financial and non-financial performance indicators are integrated with business objectives, and the degree to which these objectives have been achieved can be measured. BSC enables businesses to relate their vision, mission, and strategy to performance indicators and allows them to use both financial and non-financial criteria in the assesssment of their business performance (Kaplan and Norton, 1992).

A review of air transportation operations in Turkey shows that from the 1930s to 1983, air transportation was carried out by a single state operated airline company. With the introduction of the 1983 Civil Aviation Law, the airline market became partically deregulated and opened up to the private sector. However, certain regulations introduced after 1983 again resulted in a monopoly structure in Turkish air transportation. 2003 marked a milestone for Turkish air transportation deregulation. All restrictions on air transportation, such as market access, pricing and capacity, were removed, and domestic airline transportation was fully deregulated in 2003 (Orhan and Gerede, 2013). After deregulation in 2003, a fierce competitive atmosphere was created in the Turkish air transportation industry. Before 2003, there was only one airline company operating scheduled transportation in the market, but by 2012 , there were seven airline companies performing scheduled transportation, excluding cargo and charter airline 
businesses. In such an intense competitive environment, performance management has become a crucial factor for airline companies aiming to achieve sustainable success.

The study aims to understand performance indicators used according to BSC perspectives in airline businesses in Turkey. The specific research questions are as follows:

- What are the financial performance indicators tracked by airline companies?

- What are the customer-related performance indicators employed by airline companies?

- What are the performance indicators employed by airline companies to improve their operational processes?

- What are the performance indicators to increase organizational learning and improve growth for airline companies?

\section{Strategic Performance Management in Airline Companies}

According to Amaratunga and Baldry (2002), strategic performance management is a management system that ensures the creation of strategic objectives to further improve a company as well as accurate distribution of business resources to prioritized areas, while monitoring whether implemented policies achieve determined goals. Strategic performance management systems come in a variety of forms; however, their most important common characteristic is that they allow for an assessment of the financial and non-financial performance of a business as a whole, in accordance with its business strategy (Bento and White, 2010; Frigo, 2002).

Airline companies use financial and operational performance indicators heavily in performance measurement (Schefczyk, 1993; Francis et al., 2005). According to Francis et al. (2005), the most-widely used operational performance indicator for airline companies is the 'cost per available seat'. This is also viewed as the most important indicator in reflecting full operational performance by airline managers. Load factor and on-time performance rate are two other indicators used by more than $80 \%$ of the companies that have participated in the study.

Financial performance indicators that are frequently used by businesses provide tools for business management to determine financial weaknesses and strengths. The most frequently used performance indicators in the attainment of financial goals are operating costs, operating income, top line growth, cash flow and return on capital. Financial performance indicators and their analyses are important for the successful management of an airline company (Kane, 2012; Morrell, 2007). However, financial indicators are not adequate by themselves to assess and track whether a business strategy is successful, and thus non-financial performance indicators are needed (Neely, 1999; Schefczyk, 1993). According to Liedtka (2002), in the airline industry, certain non-financial performance indicators provide critical data that financial indicators cannot provide. Although non-financial performance is proven to be effective in achieving financial objectives, according to Francis et al. (2005) and Gudmundsson (1999; 2002), airline companies are not using non-financial performance 
indicators appropriately in certain areas, such as environment, communication, IT management, general management and marketing.

A number of studies indicate that success in non-financial performance affects financial performance in the airline industry. According to Khim et al. (2010), performance indicators regarding customer satisfaction in airline businesses are a leading indicator of the future performance of the company. The results of the same study indicate that the efforts of airline companies towards correcting their errors (for example, reducing the number of damaged baggage items) positively affect both short and long-term financial performance. According to Gudmundsson (1999), the factors leading airline companies to bankruptcy are not only financial, and whether companies will suffer future financial problems can be predicted on the basis of their non-financial performance indicators as well. According to Riley et al. (2003), the load factor of airline companies 1 and the amount of available ton kilometres are in direct ratio to their equity share values, and performance indicators regarding their market share and offered ton-kilometer amounts are related to their financial performance. In addition to these studies, Schefczyk's (1993) and Liedtka's (2002) studies also demonstrate that non-financial performance data regarding airline companies is related to their financial performance.

\section{Balanced Scorecard as a Performance and Strategic Management Tool}

Developed by Kaplan and Norton, BSC is described as a performance and strategic management tool that expresses the mission and strategy of a business by transforming them into understandable performance measurements, and thus helps to build a framework that is necessary for strategic measurement and management (Kaplan and Norton, 1992, 1999). BSC has an important function in performance management with its role in turning a strategy into application. BSC not only helps with the management of business strategy, but also in strengthening it, and the gap between strategy and application can be closed with BSC. (Kaplan and Norton, 2000; 2001; Pienaar and Penzhorn, 2000). Differing from traditional performance measurement systems by using non-financial indicators in addition to financial performance indicators, BSC has the ability to assess the success of an organization as a whole. As in other industries, in the airline industry, certain non-financial performance indicators also provide critical data that cannot be supplied by financial performance indicators (Liedtka, 2002). Viewed from this perspective, the importance of using a multi-dimensional performance management system, such as BSC, in airline businesses becomes evident. Although BSC has been widely-adopted and used in the business sector, the airline industry has not broadly embraced the concept. The results of a study by Francis et al. (2005) on 200 airline companies show that only $29 \%$ of airline companies chose to use the BSC method.

With BSC targets and indicators, the performance of a company can be analyzed from four different perspectives. These perspectives are financial, customer, internal business, and learning and growth. These four perspectives of BSC allow managers to view the organization from various angles. In this way, it becomes possible for managers to assess 
business performance, based not solely on one perspective, but to manage the performance of the organization as a whole, multi-dimensionally (Kaplan and Norton, 1996; 1999).

BSC's four basic perspectives have been found to be sufficient for various industries and businesses, but these four dimensions should be utilized as a model or a template. Of these four dimensions, some businesses may use only two or three, but depending on the industry they are operating in, or their business strategy, they may add more perspectieves (Kaplan and Norton, 1999). According to Wald (2010), unfortunately, the four traditional perspectieves of BSC do not come close to addressing the needs of the airline industry. Therefore, when building BSC for the airline company, depending on the specific characteristics of the industry, some of these traditional perspectieves can be removed and certain business-specific perspectieves can be added. In a sample BSC developed for an airline company, the traditional internal process and learning and growth perspectieves were not used, but new perspectieves of flight operation and services were added.

\subsection{Financial Perspective}

Often used besides the BSC method, financial performance indicators usually show the short-term success of an organization. In using these performance indicators, the BSC method differs from traditional performance control systems by relating financial results with the performance indicators determined by other perspectieves. The financial perspective addresses the question, "To succeed financially, how should we appear to our shareholders?" (Kaplan and Norton, 1999).

For profit-oriented airline companies, financial indicators are also the most focused on performance indicators. According to Francis et al. (2005), the most frequently-used financial performance indicators for the measurement of airline business Performance are operational cost, cash flow rate, operational income, profitability, return on invested capital, debt/equity ratio, income / expenditure ratio, price/earning ratio, share price, and earnings per share ratio. While most financial performance indicators used in airline businesses are similar to the indicators in other sectors, there are a number of financial performance indicators that are specific to the airline industry. These indicators are RPK (revenue passenger kilometers), CASK (cost per available seat kilometers), and WLU (revenue per workload unit).

\subsection{Customer Perspective}

Customer perspective addresses the question, "To achieve our vision, how should we appear to our customer?' (Kaplan and Norton, 1999). Airline service is a whole set of multi-step complex services beginning with a passenger's reservation, then airport arrival and check-in, and ending with his/her departure from the airport. (Shaw, 2011). In order to increase customer satisfaction, the performances of especially problem-prone services are measured by airline businesses. While indicators in this perspective, such as number of customers, customer complaint rates and market share are similar to performance indicators in other sectors, additional indicators based on the different characteristics of the airline industry are also used by airline businesses. Some of these additional indicators are check-in service efficiency, the quality of cabin services, the quality of onboard catering and the effectiveness 
of customer loyalty programs (Leong, 2008; Surovitskikh and Berendien, 2008) BSC indicators in customer perspective are accepted as supportive of financial performance. Studies show that customer satisfaction increases market share and profitability. Furthermore, indicators regarding customer complaints are accepted as leading indicators for long-term financial profitability projections (Khim, 2010).

\subsection{Internal Business Process Perspective}

The internal business process perspective addresses the question, "To satisfy our shareholders and customers, what business processes must we excel at?' (Kaplan and Norton, 1999). The operation process for airline businesses includes ground services, passenger services, network planning, schedule planning and maintenance. All of these processes are related to flight operation, and thus run together to ensure effective and efficient flight operation. Thus, in order to evaluate performance in internal processes, each operational department can set up their own BSC, and assess this in the light of the company BSC, within the framework of cause-and-effect relationships (Wald, 2010).

Certain services provided by airline businesses to passengers are offered by airport terminal management, and a number, such as ground service providers, are outsourced. However, airline businesses also measure the performance of these services offered to passengers by sub-contractors on their behalf. The primary reason for this is because when something goes wrong with services provided by sub-contractors, passengers hold the airline company directly accountable. Another reason for such performance measurement is that airline companies want to check their sub-contractors' service quality (Wald, 2010; Serpen, 2008).

\subsection{Learning and Growth Perspective}

Performance indicators in learning and growth perspective are becoming increasingly important for businesses that wish to stay abreast of technological developments in a rapidly-developing economic climate and to achieve long-term goals (Kaplan ve Norton, 2000). The learning and growth perspective addresses the question, "To achieve our vision, how will we sustain our ability to change and improve?" (Kaplan and Norton, 1999). In order to improve performance in this perspective, airline businesses especially focus on performance indicators regarding their human resources, environment, airline cooperations and sub-contractors (Wald, 2010; Goh and Uncles, 2002).

The quality of services offered by airline businesses is similar. When one airline company begins to offer an innovative service, this is quickly copied and applied by other companies. Therefore, to be able to differentiate themselves from their competitors, airline companies try other methods. One of the most effective ways of achieving this differentiation for airline businesses is 'personnel differentiation'. Better trained and better qualified personnel can better meet the demands of customers and can offer better quality service (Heracleous and Wirtz, 2009). Measuring human resource performance in the airline industry involves a wide range of personnel, covering ground handling personnel, administrative personnel and flight crew. Some of the human resource performance indicators in airline businesses are the number of permanent employees, manager/pilot ratio, the amount of training investment per 
employee, the accomplishment rate of planned training, and personnel satisfaction and loyalty (Wald, 2010).

For airline businesses, another significant set of performance indicators in the learning and growth perspective is environmental indicators, because airlines must minimize the damage they cause to the environment. Any negative publicity that may result from an airline company's environmental damage will indirectly affect its financial success as well (Hooper and Greenall, 2005). Some of the environmental performance indicators for airline businesses include kerosene consumption per kilometer per revenue passenger, the amount of $\mathrm{CO} 2$ emissions per ton/kilometer per revenue passenger, the number of people affected by aircraft noise, the percentage of recycled waste, and the average age of the fleet (Wald, 2010).

\section{Methodology}

This study is designed as a multiple case study, a qualitative research approache. Such design emphasizes the perspective of people involved in research issues, a description of the context where the studied phenomena occur and a timeline of events is provided in detail (Yin, 1994). A remarkable characteristic of the case study method is that it enables an in-depth analysis of ongoing events with all their dimensions in a certain context, and it also allows better insight into how and why certain decisions regarding social phenomena or events are made. There are benefits to carrying out more than one case study to improve the external validity of the findings. Moreover, regarding the perspectives of BSC, it is difficult to identify performance indicators for choosing a unique case study (Neuman, 1991; Yıldırım and Şimşek, 2008).

The research data was collected by conducting semi-structured interviews and using secondary sources. A semi-structured interview form was prepared after reviewing the BSC literature. In order to determine expert validity, the interview questions were sent to two experts to be reviewed for their scope, appropriateness, and clarity and, in the light of received feedback, the questions were finalized. The secondary data in the study was obtained from the webpages and activity reports of the airline companies.

The raw data elicited through the interviews was recorded without changes, and analyzed via content analysis. The primary purpose of content analysis is to arrive at concepts and relationships that explain the collected data. Content analysis is the classification and summarization of written texts on the basis of a certain problem or goal and sorting them into descriptive categories to evaluate certain variables or concepts to interpret them in a specific way (Hsieh and Shannon, 2005). The data collected for this study was coded and classified according to performance perspectives in the BSC literature, and interpreted by relating them to the research questions.

Within the scope of the case study, five airline companies, all major players in scheduled airline transportation in Turkey, were included. Due to the airline companies' privacy policies while participating in the study, to ensure anonymity, they are given the pseudonyms of 'Airline A', 'Airline B', 'Airline C', 'Airline D' and 'Airline E'. The respondents from these airline companies were selected through a purpose sampling method for the interviews and were responsible for the performance management of these airline companies, but their 
specific positions varied. In total, one senior manager from Airline A, one mid-level manager from Airline B, one mid-level manager and two experts from Airline C, one senior manager from Airline D, and two mid-level managers and one expert from Airline E were interviewed.

To ensure the consistency of the interview method that was used to collect data, all of the interviews were conducted by the same researcher in the same manner. In order not to influence the answers provided by the respondents, the researcher tried to introduce only minimal intervention into the interview. The interviews were carried out in the respondents' work offices and each lasted for approximately for one hour.

Additionally, after the collected data was analyzed and compiled into reports, the respondents were each e-mailed copies of the reports for their feedback. No negative comments or corrections were received as a result.

\section{Findings}

\subsection{Introduction of the Airline Companies Participating in the Study}

It is commonly thought that the performance processes and performance indicators of airline companies may vary depending on the activity year and capacity of the airline company. Therefore, the summary information for the airline companies in this study is presented below (www.shgm.gov.tr):

SunExpress Airlines was established in 1989 to run Antalya-based international charter flights, in partnership with THY and Lufthansa. After carrying out tourist charter transportation between Europe and Antalya for a period, it started scheduled flights in 2006. It currently operates with 74 planes and a 13,392 seat capacity.

- Pegasus Airlines, founded in 1990 to operate charter transportation, made Istanbul Sabiha Gökçen Airport its hub. At present, it runs domestic and international scheduled flights, operating with a 54-plane fleet and a 13.581 seat capacity.

- Onur Air began operations in 1992, and is a scheduled airline company based at Istanbul Atatürk Airport. Since 2003, it has provided domestic flights in addition to international flights. It has a 22-plane fleet and a capacity of 5.027 seats.

- AtlasJet was established in 2001 as an Istanbul-based tour operator, before moving into the scheduled passenger transportation business. It currently offers domestic and international flights with a 19-plane fleet and a seat capacity of 3.456.

- BoraJet entered the market with its regional airline model in 2008, to connect smaller Turkish cities with larger Turkish cities and only serves scheduled domestic passengers. It operates with 5 planes and a 350 seat capacity.

\subsection{Performance Indicators in Financial Perspective}

Operational costs and cost per seat are the top performance indicators that are tracked by the airline companies participating in this study. Regarding operational cost tracking, detailed cost measurements have been made. For some of the airlines the operational costs are based 
on flights, for others in the study the costs are based on an aircraft, with the remainder basing their costs on all aircraft for particular periods. In all three instances the operational costs are compared to their targeted costs. Only one of the airline companies calculates operational costs and submits the profit/loss report to management daily, and this company views itself as a low-cost focused company. Besides, in certain airline companies there is a cost control department and this department checks cost items in detail.

'Profitability' is another financial indicator that is tracked by all the airline companies. In order to increase profitability on a flight line basis, airline companies have revenue management departments which determine different seat prices to ensure maximum profitability. Since some airlines operate by renting planes, these airlines track profitability after excluding plane rental costs.

Cost per seat is tracked by all the airline companies, while revenue per seat is not tracked by most of the airlines, because the revenue created by a single seat does not mean much for the airline companies. The important thing is revenue based on a flight line for a certain period.

Apart from the above mentioned indicators, the other financial indicators tracked by the airline companies are cash flow rate, return on investment, debt/equity ratio, revenue/expenditure ratio, price / earning ratio and revenue per seat, as shown in Table 1 below. 
Table 1. Performance Indicators of Turkish Airline Companies

\begin{tabular}{|c|c|c|c|c|c|}
\hline Performance Indicators & A & B & $\mathbf{C}$ & $\mathbf{D}$ & $\mathbf{E}$ \\
\hline \multicolumn{6}{|l|}{ Financial Persperctive } \\
\hline Operational Cost & + & + & + & + & + \\
\hline Cash Flow & + & + & + & + & + \\
\hline Profitability & + & + & + & + & + \\
\hline Return on Investment & - & + & + & + & - \\
\hline Dept/Equity Ratio & + & + & + & + & - \\
\hline Income/Expenditure Ratio & - & - & + & - & + \\
\hline Price/Earning Ratio & - & - & - & - & + \\
\hline Revenue per Seat & + & - & - & - & - \\
\hline Cost per Seat & + & + & + & + & + \\
\hline \multicolumn{6}{|l|}{ Customer Perspective } \\
\hline Revenue Passenger Kilometres & + & + & + & + & + \\
\hline Service Quality in Aircraft & + & + & + & + & + \\
\hline Delivering Time of Baggage & + & + & + & + & + \\
\hline Number of Lost and Damaged Baggage Items & + & + & + & + & + \\
\hline Check-in Time & + & + & + & + & + \\
\hline Number of Customer Complaints & + & + & + & + & + \\
\hline Response Time of Such Customer Complaints & + & + & - & - & + \\
\hline Load Factor & + & + & + & + & + \\
\hline Passenger Satisfaction & + & + & + & + & + \\
\hline Market Share & + & - & - & + & - \\
\hline \multicolumn{6}{|l|}{ Internal Business Process Perspective } \\
\hline On-time Performance & + & + & + & + & + \\
\hline Average Fleet Age & + & + & + & + & - \\
\hline Available Seat Kilometres & + & + & + & + & + \\
\hline Turnaround Time & + & + & + & + & - \\
\hline Break-up Occupancy Rate & + & + & + & + & - \\
\hline Aircraft Productivity & + & - & - & + & + \\
\hline Ground Handling Time & + & + & + & + & + \\
\hline \multicolumn{6}{|l|}{ Organizational Learning and Growth Pespective } \\
\hline Personnel Satisfaction & + & - & + & + & + \\
\hline Rate of Development of New Services & - & - & + & - & + \\
\hline Personnel Productivity & + & - & - & + & + \\
\hline Amount of Personnel Training & + & + & - & + & - \\
\hline Accident and Incident Ratio & + & - & + & - & - \\
\hline Environmental Performance (Co2, noise, waste) & + & + & + & - & - \\
\hline
\end{tabular}




\subsection{Performance Indicators in Customer Perspective}

Customer perspective is a performance indicator tracked by all the airlines, prioritized on the basis of customer satisfaction. Surveys regarding in-flight service quality are conducted by the airline companies to measure customer satisfaction. Besides this type of self-tracking, customer satisfaction surveys are also carried out by independent organizations, and airlines are ranked regarding their service quality.

The number of customer complaints is measured in all the airline companies that were under review such customer complaints are collected by the airlines through in-flight passenger cards, call centers and webpages. Some of the airline companies set goals regarding their response times to such customer complaints, aiming to respond within certain time frames. Airline B also uses the ISO10002 Customer Satisfaction Management System, which is a customer-oriented approach and determining the customer complaint standard.

Indicators, such as revenue passenger per kilometer, load factor and market share that yield figures regarding customers, are also frequently used by airline businesses. However, since the scale of the market is not known by an airline company, market share performance indicators can only be measured by comparison with other airlines. While the market is a variable factor for airline companies, it is usually accepted as flight destination city pairs.

\subsection{Performance Indicators in Internal Business Process Perspective}

The performance of services provided by ground handling companies, such as baggage handling and check-in are frequently tracked by the airline companies. Most of these indicators are tracked daily for each flight. All of the airlines participating in the study outsource their ground handling services. The performance of the ground handling company is tracked by common systems shared by both the ground handling company and the airline company, with performance information being reported to the airline company by the ground handling company. The performance goals regarding these services are determined in the service contract signed by both companies. The airline company measures the performance of the sub-contract company through these goals.

From the internal business perspective of airline companies, one productivity performance indicator is load factor. In some of the airlines, the measurement of load factor is conducted for every flight, but in others it is conducted for each flight line. By dividing all the available seat kilometers by revenue seat kilometer for all the flights for determined periods, companies' load factors are calculated. According to Airline A and Airline C, load factor by flight is not a decisive performance indicator, but what counts is the load factor that covers all of the flights.

Average fleet age is an important indicator that affects airline image and the productivity of the operation and, except for Airline E, it is measured by all the airline companies. The reason this is not measured by Airline $\mathrm{E}$ is that it has a 1999 model plane which inevitably lowers the average age of its fleet.

The measurement of break-even occupancy rate is also measured on the basis of reservations made by the revenue management departments of all the airlines. 


\subsection{Performance Indicators in the Organizational Learning and Growth Perspective}

Within the learning and growth perspective, the measurements regarding personnel satisfaction are taken by all the airline companies, except for Airline B. In order to be objective, airline companies try to measure personnel satisfaction via organizational climate surveys conducted by consulting firms.

It is found that almost all of the training objectives planned for personnel are compulsory training required by the aviation authorities. Since they carry out all of this required training, the degree to which this training is realized cannot be measured. Besides such required training, Airline A, Airline B and Airline D also determine career development training for their personnel and measure the realization rate for such trainingfor each period.

The top priority in airline operations is flight safety. . To this end, Safety Management System-SMS, used by airlines to reduce risk in all aviation activities and processes to acceptable levels, measures many performance indicators. One of these indicators is accident/incident rate. The accident/incident rate is tracked by all the airline companies.

Environmental performance measurements are partially taken by the airline companies. Only Airline $\mathrm{E}$ does not have any environmental performance measurements besides those required by the aviation authorities. Performance indicators regarding emissions and aircraft noise levels are tracked more systematically in the airline companies that have intensive European flights than in the airlines which operate no European flights. The ISO14001 Environment Management System is used by Airline A and Airline B. They implement waste management plans, set goals in regard to this and check whether these are achieved at the end of the period.

The goals regarding new service development and the use of technology are set by all the airlines at the beginning of a period, but new service development rates are tracked only by Airlines $\mathrm{C}$ and $\mathrm{E}$ as performance indicators.

\section{Conclusion}

It is clear that performance measurements based only on financial criteria are not sufficient to evaluate the performance of a business. As a performance and strategic management tool, BSC enables businesses to transform their strategic objectives into financial and non-financial performance indicators. Therefore, interest in the BSC approach to strategic management continues to grow. This study considers BSC in the context of airline literature, especially for scheduled passenger airlines. Thus, this study contributes to the literature using the BSC approach for a specific industry.

This study identifies performance indicators for scheduled airline companies in Turkey within the perspectives of BSC, and it attempts to provide a basis for Turkish airline companies in their use of BSC. The interviews conducted demonstrate that airline companies are using certain performance development methods, such as Quality Management Systems, the European Foundation for Quality Management (EFQM), and benchmarking, tracking many financial and non-financial indicators. Apart from the indicators outlined in the previous section, there are many other indicators used by airline companies. However, in this 
study, within the BSC perspectives, only primary indicators for airlines are covered. A number of performance indicators used by airline companies cannot be definitively placed under BSC, because one indicator under a perspective may also be related to another perspective. For example, an indicator of operational productivity can also be an indicator of customer satisfaction.

This study shows that while there are some minor differences among airline companies in terms of the performance indicators used, the primary performance indicators are generally similar. Differences among companies are to be expected, because each airline company has a different business model and different strategic objectives and, as a result, its key performance indicators will be different as well.

Airline businesses seem to need a multi-dimensional performance management system, such as BSC to help them achieve their strategic objectives more easily. Thanks to such a performance management system, airlines can determine their critical performance indicators to accomplish strategic objectives and to build cause-effect relationships between non-financial indicators and financial performance.

By providing an assessment of its applicability, this study can be expected to assist airline companies by enlightening them about the BSC method, which is not part of current performance assessment processes of scheduled airline companies in Turkey.

\section{References}

Amaratunga, D., \& Baldry, D. (2002). Moving from performance measurement to performance management. Facilities, 20(5/6), 217-230. http://dx.doi.org/10.1108/02632770210426701

Bento, A., \& White L.F. (2010). An exploratory study of strategic performance measurement systems. Advances in Management Accounting, 18, 1-26. http://dx.doi.org/10.1108/S1474-7871(2010)0000018004

CIMA Technical Briefing, (2002). Latest trends in corporate performance measurement. Retrieved from http://www.cimaglobal.com/Documents/ImportedDocuments/tech_techbrief_latest_trends_07 02.pdf

Doganis, R. (2002). The Airline Business in the Twenty-First Century. London: Routledge.

Francis, G., Humphreys, I., \& Jackie, F. (2005). The nature and prevalence of the use of performance measurement techniques by airlines. Journal of Air Transportation Management, 11(4), 207-217.

Gudmundsson, S. V. (1999). Airline failure and distress prediction: A comparison of quantitative and qualitative models. Transportation Research: Part E, 35, 155- 182.

Gudmundsson, S. V. (2002). Airline distress prediction using non-financial indicators. Journal of Air Transportation, 7(2), 1-24. 
Goh, K., \& Uncles, M. (2002). The benefits of airline global alliances: an empirical assessment of perceptions of business travelers. School of Marketing Working Paper, 1(5), 1-30. Retrieved from file:///C:/Users/User/Desktop/Uncles_Goh01_5\%20(1).pdf

Heracleous, L., \& Wirtz, J. (2009). Strategy and organization at Singapore Airlines: Achieving sustainable advantage through dual strategy. Journal of Air Transport Management, 15(6), 274-279.

Hooper, P. D., \& Greenall, A. (2005). Exploring the potential for environmental performance benchmarking in the airline sector. Benchmarking an International Journal, 12(2), 151-16. http://dx.doi.org/10.1108/14635770510593095

Hsieh, H., \& Shannon, S. E. (2005). Three approaches to qualitative content analysis. Qualitative Health Research, 15(9), 1277-1288. Retrieved from http://qhr.sagepub.com/content/15/9/1277

Frigo, M. L. (2002). Strategy-focused performance measures. Strategic Finance, 84(3), $10-15$.

Kane, R. M. (2012). Air Transportation. (16th ed.). Dubuque: Kendal/ Hunt Publishing.

Kaplan, R. S., \& Norton, D. P. (1992). The balanced scorecard-measures that drive performance. Harvard Business Review, (January - February), 71 - 79.

Kaplan, R. S., \& Norton, D. P. (1996). Linking balanced scorecard to strategy. California Management Review, 39(1), 53 - 79.

Kaplan, R. S., \& Norton, D. P. (1999). Balanced Scorecard: Şirket Stratejisini Eyleme Dönüş̧ürmek. (2th ed.). İstanbul: Sistem.

Kaplan R. S., \& Norton, D. P. (2000). Having trouble with your strategy? Then map it. Harvard Business Review, (September- October), 167-176.

Kaplan, R. S., \& Norton D. P. (2001).Transforming the balanced scorecard from performance measurement to strategic management: part I. American Accounting Association Horizons, 15(1), 87 -104. http://dx.doi.org/10.2308/acch.2001.15.1.87

Khim, L. S., Chang, C. S., \& Larry, N. K. (2010). Service quality, service recovery, and financial performance: an analysis of the US airline industry. Advances in Management Accounting, 18, 27 - 53. http://dx.doi.org/10.1108/S1474-7871(2010)0000018005

Leong, C.C. (2008). An importance-performance analysis to evaluate airline service quality: the case study of a budget airline in Asia. Journal of Quality Assurance in Hospitality \& Tourism, 8(3), 39-59. http://dx.doi.org/10.1080/15280080802080193

Liedtka, S. L. (2002). The information content of nonfinancial performance measures in the airline industry. Journal of Business Finance \& Accounting, 29(7), 1105 - 1121. Retrieved from http://onlinelibrary.wiley.com/doi/10.1111/1468-5957.00463/pdf

Morrell, P. S. (2007). Airline Finance. (3rd ed.). Hampshire: Ashgate. 
Neely, A. (1999). The performance measurement revolution: why now and what next? International Journal of Operations \& Production Management, 19(2), 205-228. http://dx.doi.org/10.1108/01443579910247437

Neely, A., Gregory, M., \& Platts, K. (2005). Performance measurement system design. International Journal of Operations \& Production Management, 25(12), 1228-1263. http://dx.doi.org/10.1108/01443579510083622

Neumann, W. L. (1991). Social Research Methods: Qualitative and Quantitative Approaches. Boston: Allyn and Bacon.

Pienaar, H., \& Penzhorn, C. (2000). Using the balanced scorecard to facilitate strategic management at an academic information service. Libri 50(3), $202-209$.

Riley, R. A., Pearson, T. A., \& Trompeter, G. (2003). The value relevance of non-financial performance variables and accounting information: the case of the airline industry. Journal of Accounting and Public Policy, 22(3), 231-254. Retrieved from http://www.sciencedirect.com/science/article/pii/S0278425403000218

Orhan, G., \& Gerede, E. (2013). A study of the strategic responses of Turkish airline companies to the deregulation in Turkey. Journal of Management Research, 5(4), 34 - 63. http://dx.doi.org/10.5296/jmr.v5i4.4201

Republic of Turkey Ministry of Transport, Maritime Affairs and Communications Directorate General of Civil Aviation. Retrieved from www.shgm.gov.tr

Schefczyk, M. (1993). Operational performance of airlines: an extension of traditional measurement paradigms. Strategic Management Journal, 14(4), 301-317. Retrieved from http://www.jstor.org/stable/2486797

Serpen, E. (2008).Airline productivity improvement. IATA/IGHC Ground Operations Symposium, Kuala Lumpur. Retrieved from http://www.she.com/presentations/eserpen_12_may_08.pdf

Shaw, S. (2011). Airline Marketing. (6th ed.). Burlington: Ashgate.

Surovitskikh, S., \& Lubbe, B. (2008). Positioning of selected Middle Eastern airlines in the South African business and leisure travel environment. Journal of Air Transport Management, 14(2), 75-81.

Wald, A., Christoph, F., \& Gleich, R. (2010). Introduction to Air Transportation. London: Transaction Publishers.

Yıldırım, A., \& Şimşek, H. (2008). Sosyal Bilimlerde Nitel Araştırma Yöntemleri. Ankara: Sekin.

Yin, R. K., (1994). Case Study Research: Design and Methods. London: Sage. 